\section{Antonia Vodanović}

samostalna istraživačica / independent researcher Ivana Gorana Kovačića 14a, Podgora antonia.vodanovic1@gmail.com

Prethodno priopćenje / Preliminary communication UDK / UDC: 728.82(497.5 Makarska)"17" DOI: 10.17685/Peristil.59.5

19. 7. 2016.
Dva barokna ladanjsko-gospodarska sklopa obitelji Ivanišević u Makarskoj

Ključne riječi: Makarska, barok, stambena arhitektura, 18. stoljeće, obitelj Ivanišević, Tomaso Miraglia Keywords: Makarska, Baroque, residential architecture, $18^{\text {th }}$ century, the Ivanišević family, Tomaso Miraglia

U radu se osvrćemo na palaču obitelji Ivanišević u Makarskoj, uz pojedine korekcije i nadopune, te detaljniju arhitektonsku analizu. Također, proi se put iznose podaci o drugoj gradskoj palači ove obitelji u Makarskoj i uništenom obiteljskom ljetnikovcu u Podgori. Majstoru Tomasu Miraglii iz Apulije pripisuje se izrada bunarske krune s grbom biskupa Stjepana Blaškovića, danas smještena u vrtu franjevačkog samostana u Makarskoj.

Obitelj Ivanišević u Makarsku se doselila iz Mostara 1695. godine, gdje je vrlo brzo stekla ugled, pa je tako 1700. providur Alvise Mocenigo odlučio da se obitelji Filipa Ivaniševića, zbog njegovih zasluga, dodijeli status povlaštenika. ${ }^{1}$ Filipov sin Antun bio je jedna od najistaknutijih i aktivnijih kulturnih ličnosti u gradu tijekom 18. stoljeća. ${ }^{2}$ Godine 1763. primljen je u makarsko plemstvo, dok je potvrdu plemstva za sebe i svoje potomke dobio 1772. godine. Od austrijske vlasti, priznanje starog plemstva dobili su 1829. braća Jakov Albert i Klement Ante, sinovi pokojnog Ivana, te njihov rođak Frane, sin pokojnog Filipa. ${ }^{3}$

Obitelj je trgovinom stekla velik imetak na Makarskom primorju. Jakov Ivanišević, primjerice, u drugoj je polovini 18. stoljeća kupovao vino u Gornjem primorju od seljaka te ga zatim preprodavao u Veneciji, a zemljišne posjede širili su i naplatom dugova seljacima. ${ }^{5}$

Osim brojnih zemljišnih posjeda, u 18. stoljeću obitelj je posjedovala dva stambeno-gospodarska sklopa u Makarskoj, kuću u Makru, kao i ladanjsko-gospodarske sklopove u Tučepima, Igranama i Gradcu. ${ }^{6}$ Posjedovali su i dvokrilni ljetnikovac L-tlocrta u Podgori, smješten na morskoj obali, na području Crnog dola, zapadno od ljetnikovca obitelji
Mrkušić. Sudeći prema austrijskom katastru iz 1835. godine, s južne strane imao je zidom ograđeno dvorište ispred kojeg se prostiralo morsko žalo i pružao pogled prema otocima sa sjeverne stambene katnice. Neposredno uz istočno gospodarsko krilo tekao je potok Crni dol, dok je sklop sa sjeverne i zapadne strane bio omeđen voćnjakom i maslinikom Ivaniševića te pašnjakom s ruševnom gospodarskom kućicom. ${ }^{7}$ Nažalost, do danas se od njega ništa nije sačuvalo.

\section{»Južna« palača Ivanišević u Makarskoj}

Nabrajajući "mnoge starije dosta interesantne zgrade« $u$ Makarskoj u kojima su nekad stanovali »makarski plemići«, M. Kecskemety tek usputno spominje kuću Ivanišević. ${ }^{8}$ Kratki opis njezina reprezentativnog pročelja s arkadama te stubišta donosi C. Fisković ističući iznimnu rijetkost drvene ogradice s balustrima »dvostruke kruške« gornje galerije. Autor donosi i dio tlocrta palače te nacrt njezina sjevernoga dvorišnog krila. ${ }^{9}$ K. Prijatelj također je usputno spominje 


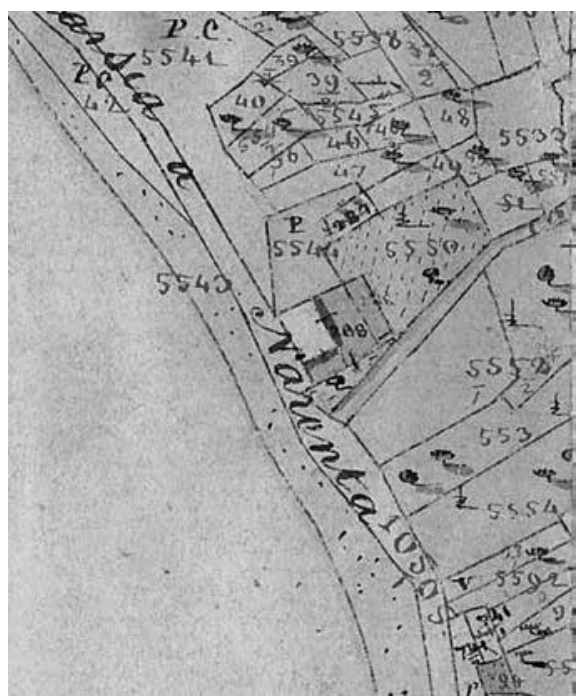

1. Katastarski nacrt ljetnikovca obitelji Ivanišević u Podgori iz 1835. godine (Državni arhiv u Splitu) / Cadastral map of the Ivanišević family villa in Podgora, 1835 (State Archives in Split)

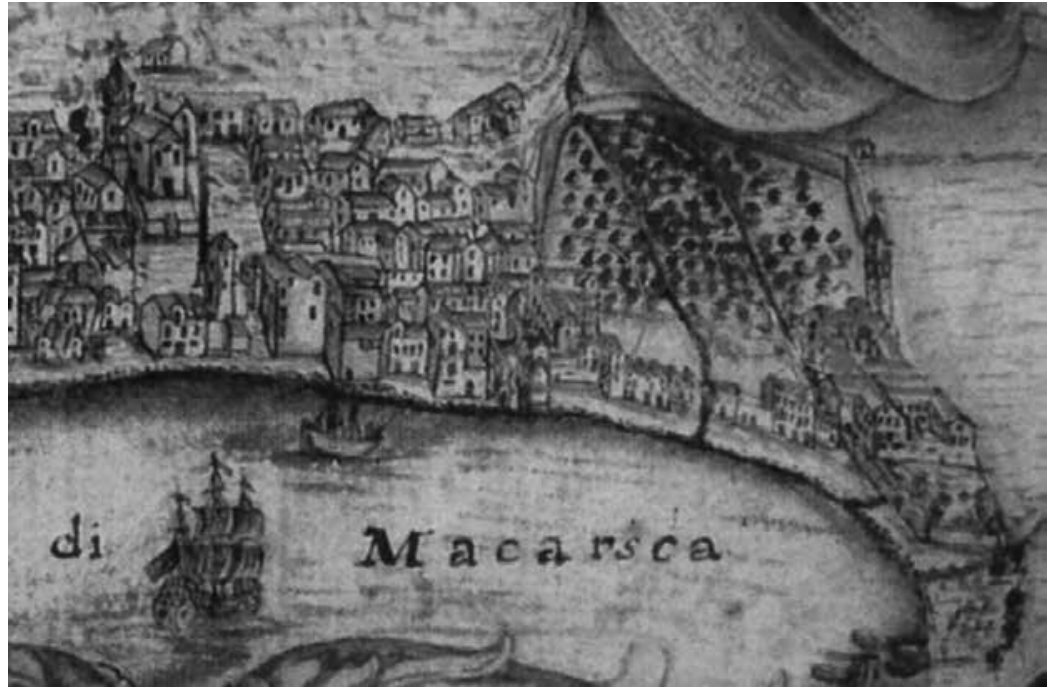

2. Detalj naslovnice katastika franjevačkog samostana u Makarskoj iz 1767. godine s naznačenim (zaokruženo) položajem palača obitelji Ivanišević (Pietro Corir, arhiv franjevačkog samostana u Makarskoj) / Detail of the title page of the Cadastre of the Franciscan convent in Makarska, 1767, with indicated position of the Ivanišević family palaces (Pietro Corir, Archives of the Franciscan convent in Makarska) naglašavajući da palača " predstavlja rijedak i zanimljiv primjer profane barokne arhitekture u Dalmaciji.$^{10} \mathrm{~K}$. Mucić sumira već poznate podatke, međutim pogrešno tvrdi da je nad ulaznim vratima palače nekad stajao »romantički oblikovan obiteljski grb Ivaniševića« koji se danas nalazi »iznad ulaza kuće na Maloj obali 8 «. ${ }^{11}$ Naime, grb se nalazi in situ na palači Ivaniševića sagrađenoj krajem 19. stoljeća, a nikako nije riječ o njegovoj dislokaciji. Z. Demori Staničić prvi put palaču sasvim ispravno naziva "gradsko-ladanjskim sklopom « te je sagledava u kontekstu ostale ladanjske arhitekture Makarskog primorja. ${ }^{12}$

S obzirom na to da se ovaj dvokrilni sklop do sada najčešće datirao u drugu polovinu 18. stoljeća, treba reći da je obje gradske palače Ivaniševića u Makarskoj katastarski ucrtao mjernik Pietro Corir 1767. godine u katastik franjevačkog samostana, stoga tu godinu možemo uzeti kao terminus post quem non njihovih gradnji. ${ }^{13}$ P. Corira za izradu je ovog katastra angažirao najistaknutiji član ove obitelji u 18. stoljeću, već spomenuti Antun Ivanišević koji je u to vrijeme bio apostolski sindik samostana. ${ }^{14} \mathrm{U}$ austrijskom katastru iz 1835. godine kao vlasnici južnog sklopa vode se Antunov sin don Pavao kojem je pripadalo zapadno krilo i dvorište (čest. 20 i 22), te unuk Franjo koji je bio u posjedu reprezentativnoga sjevernog krila rastvorenog arkadama (čest. 21). ${ }^{15}$

Dvokrilna palača podignuta je iza ostataka istočne gradske kule nekoć vezane bedemom sa zapadnom i sjevernom kulom čija je gradnja 1568. godine, za vrijeme osmanske uprave, povjerena slavnom graditelju Hajrudinu. S obzirom na pretpostavljeno pružanje gradskih zidina, izgradnja palača na ovom području nije bila moguća prije rušenja utvrde 1646. godine od strane Mlečana te širenja grada izvan njezinih parametara. Sudeći prema katastarskom nacrtu P. Corira iz 1767. godine i austrijskom iz 1835., palača se izvorno sastojala od dva krila, zapadnog i sjevernog, dok je istočno krilo podignuto negdje sredinom ili u drugoj polovini 19. stoljeća kada je sklop od izvornog L-tlocrta poprimio U-tlocrt. ${ }^{16}$ Palaču je s istočne i južne strane opasavao visok zid zatvarajući dvorište popločano kaldrmom. Dio ovoga visokog zida iz 18. stoljeća što je u jednu ruku štitio sklop podignut na samom rubu grada, a u drugu omogućavao intimu članovima obitelji, sačuvao se s ulazne južne strane. Na tom mjestu sačuvan je i pravokutni dvorišni portal tipa porta bastonata, iznad kojeg je profilirani vijenac, kakvi su česti u arhitekturi 17. i 18. stoljeća na Makarskom primorju.

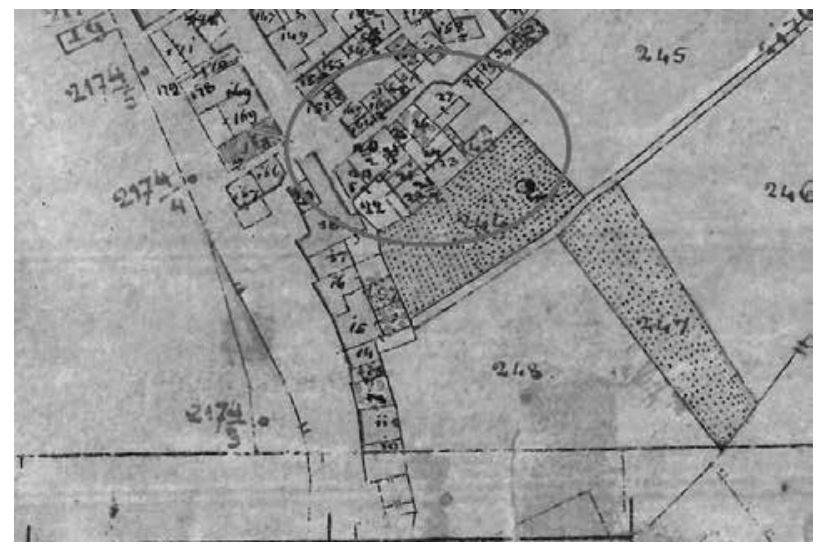

3. Katastarski nacrt zgrada u posjedu obitelji Ivanišević u Makarskoj (zaokruženo) iz 1835. godine (Državni arhiv u Splitu) / Cadastral map of buildings owned by the Ivanišević family in Makarska (circled), 1835 (State Archives in Split) 


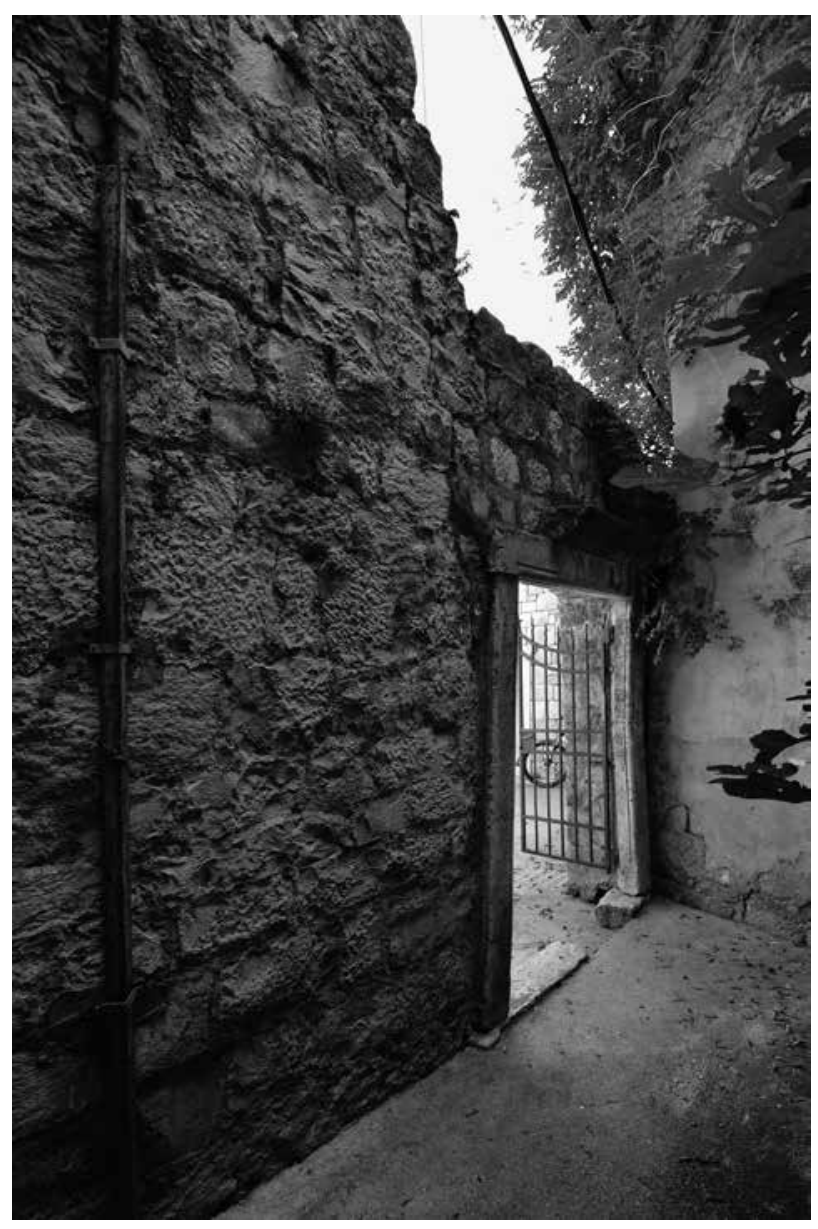

4. Dvorišni zid »južne« palače obitelji Ivanišević u Makarskoj iz 18. stoljeća (foto: A. Vodanović) / Courtyard wall of the "south" palace of the Ivanišević family in Makarska, $18^{\text {th }}$ century (photo: A. Vodanović)

U jednostavnom obliku, izrazito plošno i lišeno ukrasa, građeno je zapadno dvokatno krilo s dućanima u prizemlju i stambenim jedinicama na katovima, gdje se nekoć nalazila i bogata knjižnica. Njegovo zapadno ulično pročelje rastvoreno je tek dvama nizovima po četiri jednostavna prozora iznad kojih su profilirani vijenci, dok su otvori u prizemlju zamijenjeni recentnim, izuzev jednoga manjeg prozorčića. Ono se pak u svojoj sjevernoj četvrtini uzdiže, a u njegov zabat smješten je još jedan prozor, ispod kojeg su dvije kamene konzole. Jedini ukras zapravo je rustični pupoljak na jugozapadnom uglu ovoga krila zasječenom radi olakšavanja prometa kolima. Južno lice na katovima raščlanjeno je jednakim prozorima kao i istočno, iznad kojih je balkon postavljen na dvije konzole. Po sredini krova izdiže se trokutasti zabat profiliranih okvira, danas neprimjetan zbog naknadno sagrađenih stambenih objekata koji ga zaklanjaju. Istočna dvorišna strana zidana od neobrađenog kamena povezanog s dosta žbuke rastvorena je trima prozo-

5. Zapadno krilo »južne« palače Ivanišević u Makarskoj (foto: A Vodanović) / West wing of the "south" palace of the Ivanišević family in Makarska (photo: A. Vodanović)

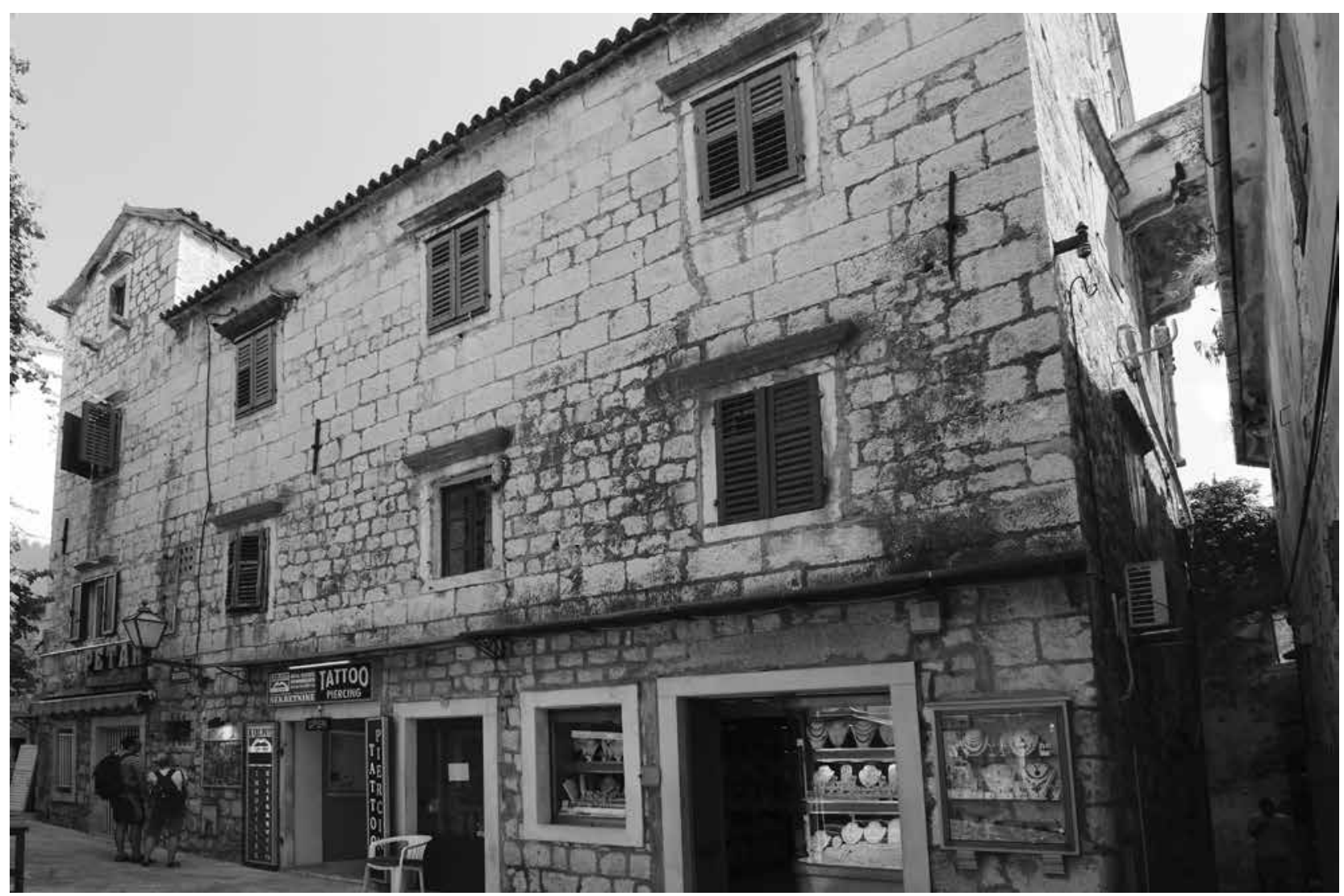




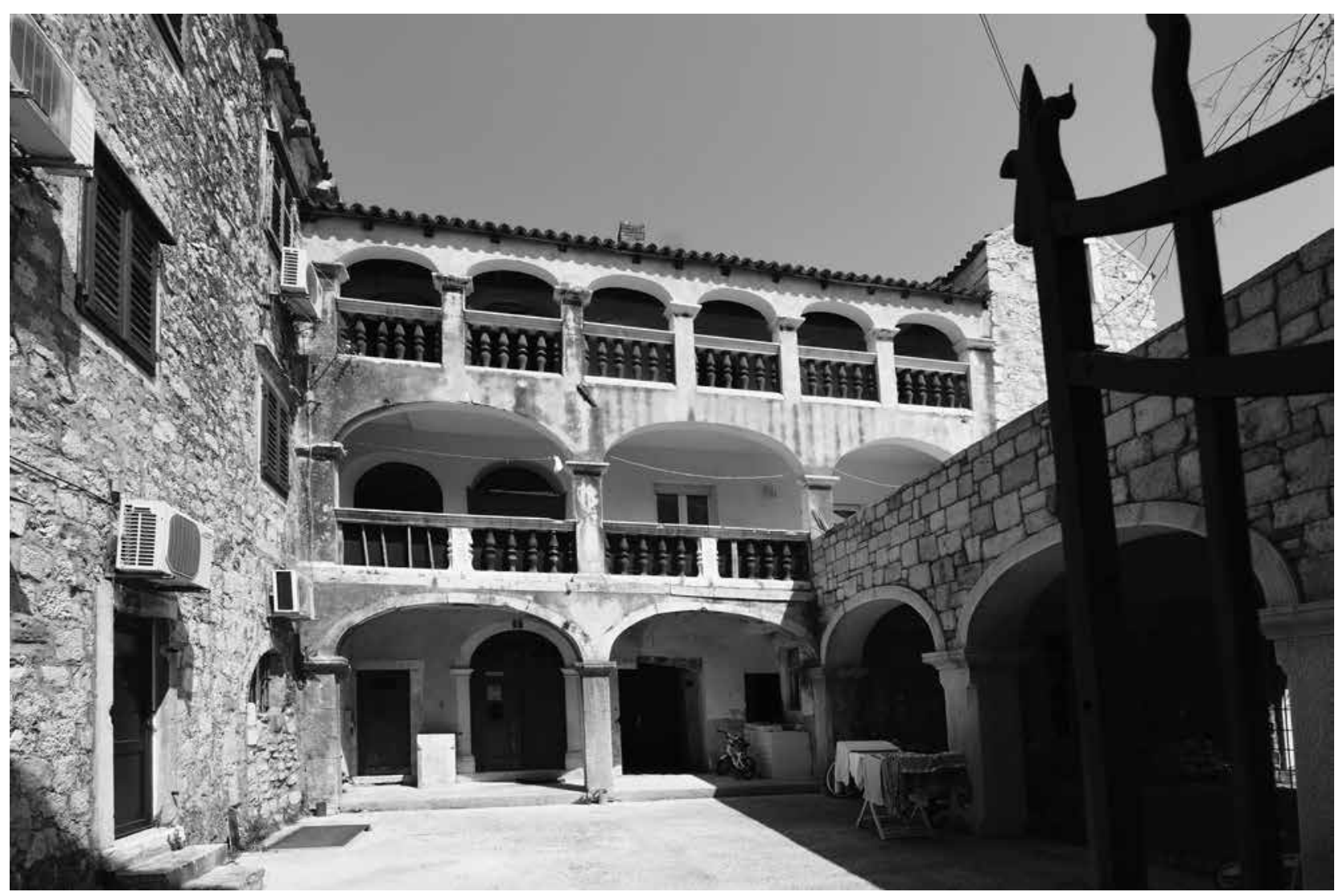

6. Pogled na sjeverno krilo »južne« palače Ivanišević u Makarskoj (foto: A. Vodanović) / View of the north wing of the "south" palace of the Ivanišević family in Makarska (photo: A. Vodanović)

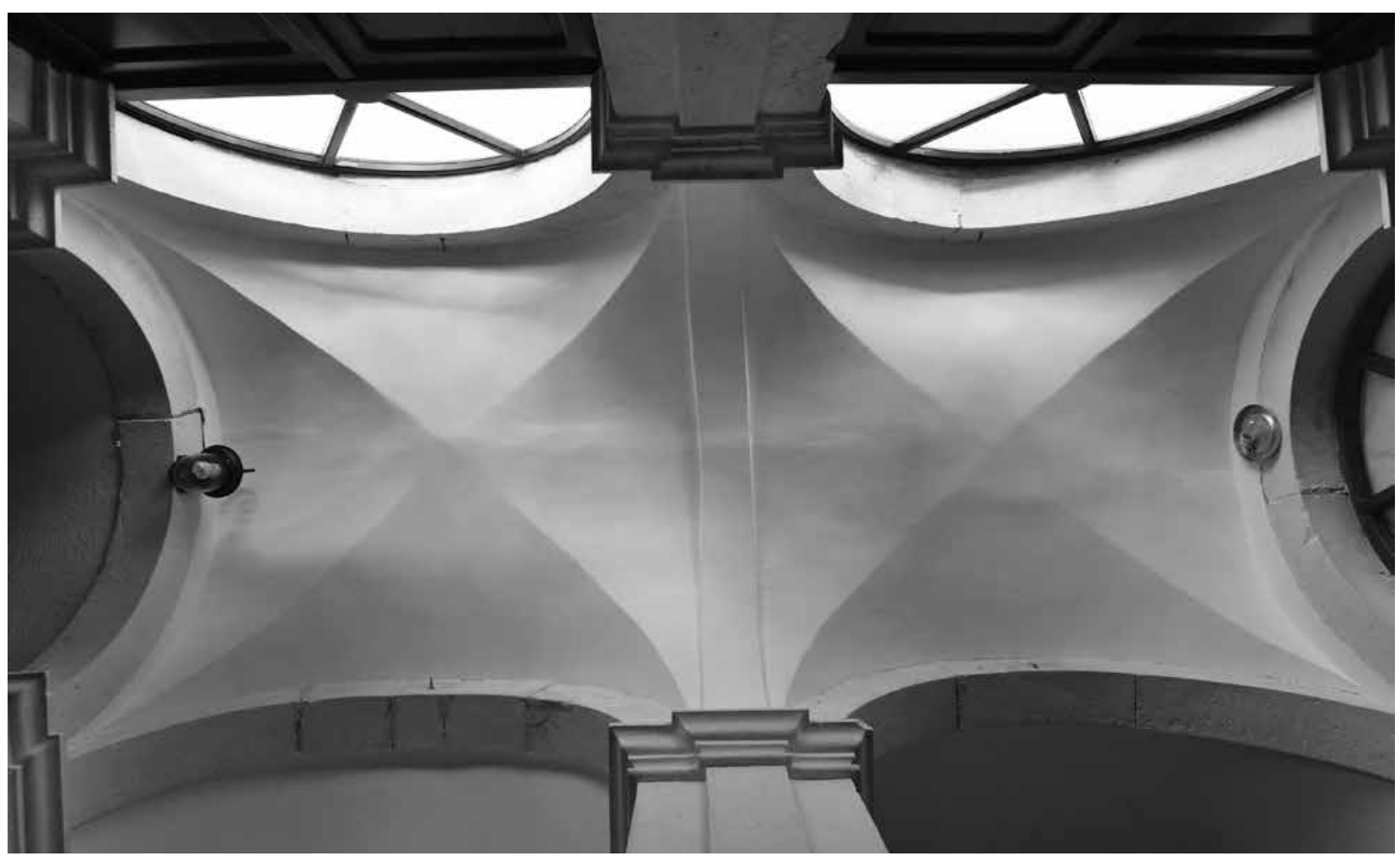

7. Križni svod podesta stubišta prvog kata »južne« palače Ivanišević u Makarskoj (foto: A. Vodanović) / Groin vault of the first floor staircase landing in the "south" palace of the Ivanišević family in Makarska (photo: A. Vodanović) 

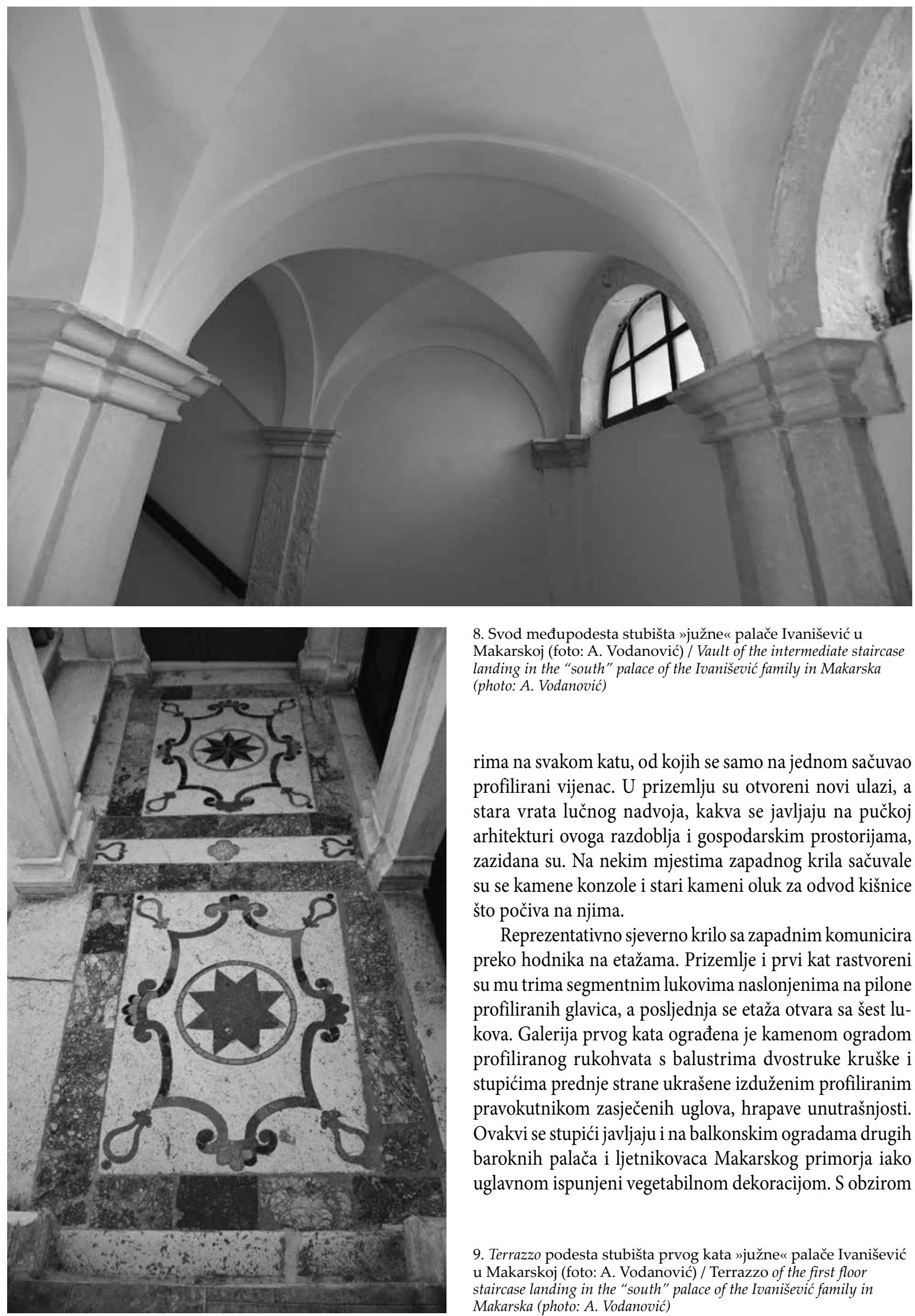

8. Svod međupodesta stubišta »južne « palače Ivanišević u Makarskoj (foto: A. Vodanović) / Vault of the intermediate staircase landing in the "south" palace of the Ivanišević family in Makarska (photo: A. Vodanović)

rima na svakom katu, od kojih se samo na jednom sačuvao profilirani vijenac. U prizemlju su otvoreni novi ulazi, a stara vrata lučnog nadvoja, kakva se javljaju na pučkoj arhitekturi ovoga razdoblja i gospodarskim prostorijama, zazidana su. Na nekim mjestima zapadnog krila sačuvale su se kamene konzole i stari kameni oluk za odvod kišnice što počiva na njima.

Reprezentativno sjeverno krilo sa zapadnim komunicira preko hodnika na etažama. Prizemlje i prvi kat rastvoreni su mu trima segmentnim lukovima naslonjenima na pilone profiliranih glavica, a posljednja se etaža otvara sa šest lukova. Galerija prvog kata ograđena je kamenom ogradom profiliranog rukohvata s balustrima dvostruke kruške i stupićima prednje strane ukrašene izduženim profiliranim pravokutnikom zasječenih uglova, hrapave unutrašnjosti. Ovakvi se stupići javljaju i na balkonskim ogradama drugih baroknih palača i ljetnikovaca Makarskog primorja iako uglavnom ispunjeni vegetabilnom dekoracijom. S obzirom

9. Terrazzo podesta stubišta prvog kata »južne« palače Ivanišević u Makarskoj (foto: A. Vodanović) / Terrazzo of the first floor staircase landing in the "south" palace of the Ivaniševic family in Makarska (photo: A. Vodanović) 
na to da je ovo krilo sa stambenim prostorijama na katovima i privatnom unutrašnjom kapelicom na prvom katu u vrijeme izgradnje palače imalo otvoren pogled prema otocima i moru, ${ }^{17}$ galerija je služila za odmor i uživanje u pogledu, ostvarujući svoj ladanjski karakter na rubu grada, okružena $s$ istočne strane maslinicima.

Glavni lučni portal prizemlja nije u središnjoj osi krila nego je izmaknut u zapadnu polovicu. Kroz njega se pristupa začelnom stubištu u osi predvorja tzv. osovinske koncepcije, ${ }^{18}{ }^{1}$ ciji su podesti nadsvođeni križnim svodovima. Unutrašnjost je nažalost izmijenjena pa tako danas nedostaju reljefne glave anđela u štuku, nekoć smještene iznad vrata prostorija kojima se pristupalo iz stubišta, ${ }^{19}$ kao i štukature iz salona na katovima. ${ }^{20}$ Sačuvao se terrazzo na podestima stubišta. U prizemlju sjevernog krila jednostavna pravokutna vrata zapadno od glavnog ulaza u palaču vode u spremište ispod stubišta, dok se istočno od njega nalazi hodnik kojim se pristupalo u dvorište danas nepostojećega drugog sklopa Ivaniševića o kojem će biti riječi dalje u tekstu. Kroz ovaj hodnik također se pristupalo gospodarskoj prostoriji u istočnom dijelu prizemlja krila.

\section{»Sjeverna« palača Ivanišević u Makarskoj}

Obitelj Ivanišević u 18. je stoljeću na istočnom rubu grada posjedovala još jednu palaču. Sudeći prema Corirovu katastarskom prikazu iz 1767. godine, palača je imala dvokrilni L-tlocrt, a dimenzijama nije zaostajala za drugom palačom ove obitelji, smještenom južno od nje, u neposrednoj blizini. Svoju tlocrtnu dispoziciju očito je sačuvala i početkom 19. stoljeća jer je na planu Makarske iz 1804., kao i onom iz 1805. godine ponovno ucrtana kao dvokrilno zdanje. ${ }^{21}$ Kroz naredna tri desetljeća doživjela je izmjene i pregradnje vidljive na austrijskom katastarskom planu iz 1835. godine. $\mathrm{U}$ ovo vrijeme sklop je već znatno devastiran te je izgubio svoju tlocrtnu dispoziciju iz 18. stoljeća. Južni dio zapadnog krila navodi se kao ruševina, a ostatak stambenog krila (Casa d’abitazione con cisterna) poprimio je asimetričan tlocrt..$^{22} \mathrm{Na}$ uličnoj pročelnoj fasadi današnje stambene katnice na tom se mjestu u pregradnjama sačuvao njezin široki pravokutni barokni portal iz 18. stoljeća obrubljen štapom, tzv. porta bastonata. Iznad nadvratnika na čijim se krajevima nalazi motiv kvadrata odsječenih rubova jest jastučasti friz ukrašen u sredini i na krajevima šesterolatičnim cvjetovima upisanim unutar kruga. Iznad je izbočeni, stepenasto profilirani vijenac. Slične portale nalazimo i na drugim baroknim palačama i ljetnikovcima Makarskog primorja: primjerice, glavni portal Grubišićeva ljetnikovca u Tučepima iz 1766. godine, zatim južni portal zapadnog krila palače Dudan na Marineti u Makarskoj iz prve polovine 18.

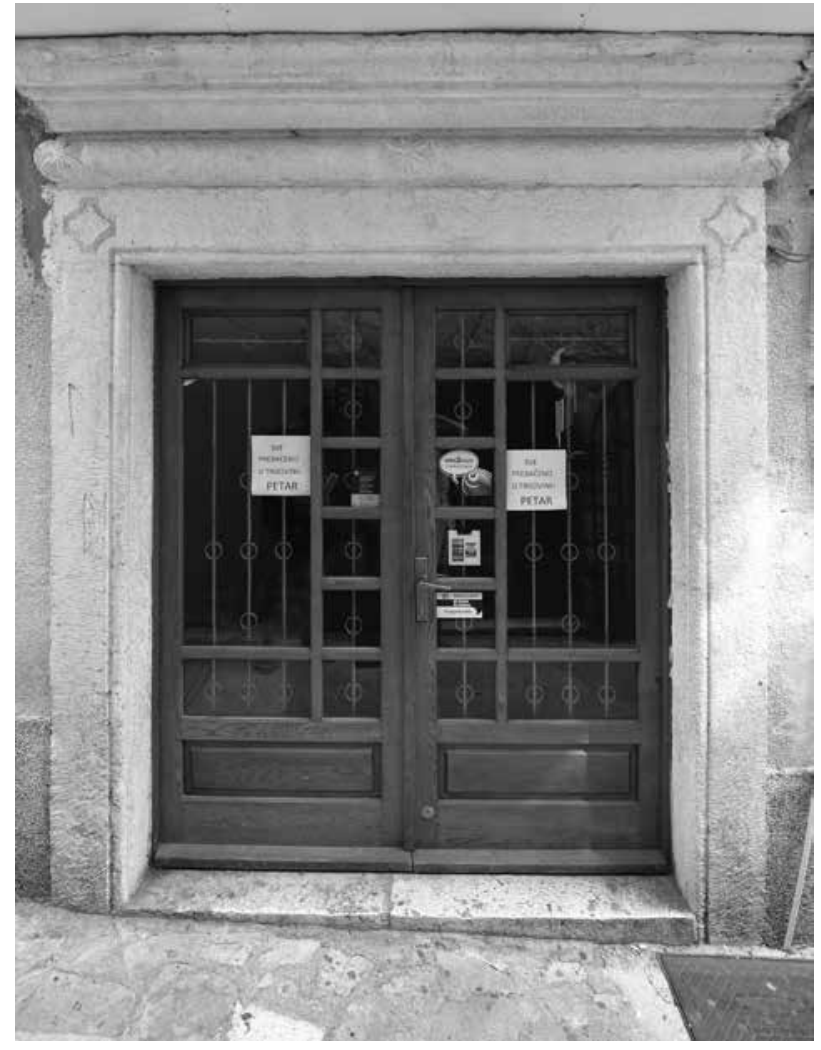

10. Portal nekadašnje »sjeverne« palače obitelji Ivanišević u Makarskoj (foto: A. Vodanović) / Portal of the former "north" palace of the Ivaniševic family in Makarska (photo: A. Vodanović)

stoljeća, južni portal sklopa Kačića istočno od katedrale sv. Marka u Makarskoj iz oko 1700., te portal iz 1787. godine na Kalelargi u Makarskoj.

Sjeverni sklop Ivaniševića u Makarskoj jedini je privatni objekt u gradu koji se u austrijskom katastru navodi da je con cisterna. ${ }^{23}$ Njegova kruna iz 17.-18. stoljeća, ${ }^{24}$ kružnog dna i kvadratnog otvora, dislocirana je te danas leži odbačena $\mathrm{u}$ vrtu sa stražnje strane novopodignutog sklopa kojim je izbrisana starija barokna građevina. Bunar se vjerojatno nalazio u dvorištu palače kojeg su zatvarala krila sklopova i

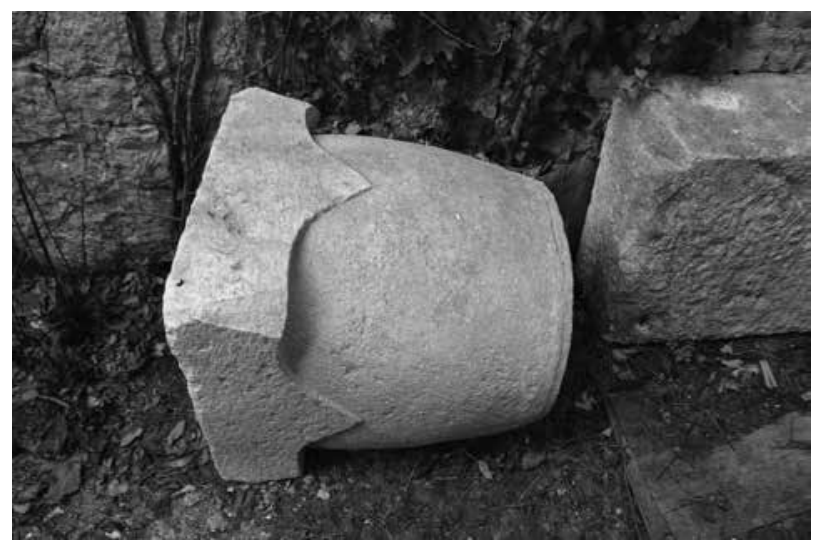

11. Kruna bunara uništene »sjeverne" palače obitelji Ivanišević u Makarskoj (foto: A. Vodanović) / Wellhead of the former "north" palace of the Ivanišević family in Makarska (photo: A. Vodanović) 

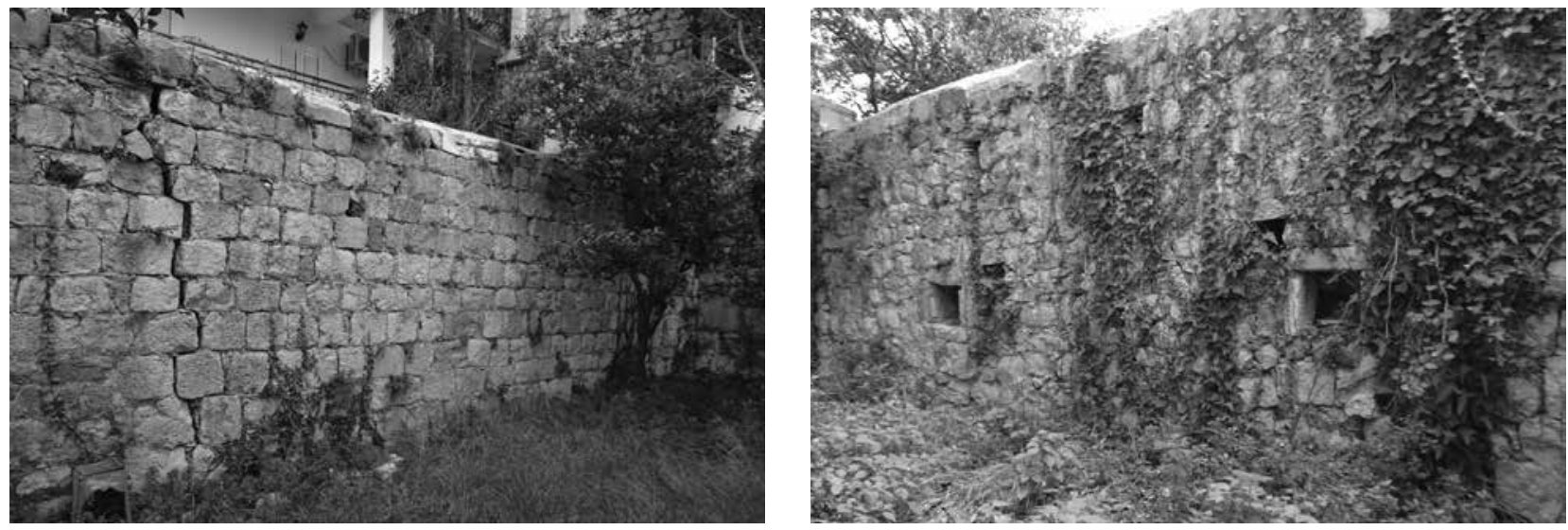

12. Ostaci dvorišnog zida (vanjsko i unutrašnje lice) »sjeverne« palače obitelji Ivanišević u Makarskoj (foto: A. Vodanović) / Remains of the courtyard wall (front and back) of the "north" palace of the Ivanišević family in Makarska (photo: A. Vodanović)

visoki zid s istočne strane, a gdje je bio i izvor bočate vode. ${ }^{25}$ Izuzev krune bunara Ivaniševića, u klaustru nedaleko smještenoga franjevačkog samostana nalazi se jedna istog tipa iz 17. stoljeća. U vrtu istog samostana nalazi se kruna bunara iz sredine 18. stoljeća koju je dao izraditi makarski biskup Stjepan Blašković, a izvorno se nalazila u dvorištu filipinskog oratorija na makarskoj rivi. Na potonjoj stoji neodgonetnuta sigla s potpisom nevještog klesara: ${ }^{26}$

MI: TO:

MI: SC:

Predlažem sljedeće čitanje kratica:

MI(STRO): TO(MASO):

MI(RAGLIA): SC(ULPTOR):

Majstor pod ovim imenom (Magistro Tomaso Miraglia tagliapietra) dana 1. travnja 1753. godine sklopio je ugovor s Antunom Ivaniševićem iz Makarske o klesanju kamenica za ulje. ${ }^{27}$ Ujedno je i jedini zabilježeni majstor koji djeluje u Makarskoj za vrijeme biskupa Stjepana Blaškovića, a čiji inicijali odgovaraju sigli. Riječ je o doseljeniku iz Apulije čije se prezime u makarskim maticama prvi put javlja 1746. godine. ${ }^{28} \mathrm{U}$ obližnjoj je Podgori 1744. sklopio brak s Katom Bratošević iz Čepikuća. ${ }^{29}$ Bio je i član Bratovštine Dobre Smrti u Makarskoj čiji je jedan od najistaknutijih članova bio upravo Antun Ivanišević, suosnivač bratovštine. ${ }^{30}$ Radio je i na gradnji zvonika makarske katedrale sv. Marka 1760. godine, upravo u vrijeme kada je prokurator njezine gradnje bio spomenuti Antun Ivanišević, a nadležan za gradnju bio je tadašnji biskup Stjepan Blašković. ${ }^{31}$ Zacijelo je otprije uspostavljena suradnja majstora T. Miraglie s biskupom i prokuratorom gradnje katedrale pogodovala njegovu zapošljavanju na gradnji zvonika prema projektu inženjera Angela Janšića.

Svojim kulturnim, društvenim, političkim te duhovnim radom i nastojanjima članovi obitelji Ivanišević zadužili su Makarsku i pripadajuće joj Makarsko primorje. Njihove dvije gradske palače u Makarskoj, kao iljetnikovci u Tučepima, Podgori, Igranama i Gradcu svjedoče o velikom imetku koji je obitelj stekla nakon dolaska u Makarsku krajem 17. stoljeća. Sudjelovanjem u mletačko-turskim ratovima stekli su naklonost Serenissime te privilegirani status, a zatim i status plemstva, što im je uz trgovačke sposobnosti donijelo istaknutu društvenu poziciju. Iako su arhitektonski sklopovi koje su podizali na samoj morskoj obali na osamljenim pozicijama imali ladanjski karakter, istodobno su imali i jaku gospodarsku ulogu zbog bavljenja lovom srdela, kao i prodajom ulja i vina, stoga su bili i mjesta za skladištenje ali i preradu sirovina. Nažalost, nebrigom ti su arhitektonski dragulji s vremenom znatno devastirani. Neki su izbrisani do temelja, a drugima se postojanje tek nazire u nekom preživjelom arhitektonskom elementu.

\section{BILJEŠKE}

1 TATIJANA GARELJIĆ, Grbovi i rodoslovi Makarske i Makarskog primorja, Gradski muzej Makarska, Makarska, 1996., 42.

2 Bio je makarski sudac, prokurator gradnje katedrale sv. Marka (1738.1756.) u Makarskoj, suosnivač Bratovštine Dobre Smrti u istoj katedrali (1723.) i njezin prvi predstojnik, zatim apostolski sindik franjevačkog samostana u Makarskoj te subrat Franjevačke provincije Presvetog Otkupitelja u Dalmaciji. TATJANA RADAUŠ, KARLO JURIŠIĆ, "Ivanišević (Degl' Ivanissevich, Iuaniseuich, Ivanischevich, Ivanisevich, Ivanisseuich)«, Hrvatski biografski leksikon, sv. 6: I-Kal, (ur.) Trpimir Macan, Leksikografski zavod »Miroslav Krleža«, Zagreb, 2005., 140-142; NEVENKA BEZIĆ-BOŽANIĆ, Prilog poznavanju bratovština u Makarskoj u 18. stoljeću, Makarsko primorje, 1 (1990.), 103-114. Uz dopuštenje pape Benedikta XIII., godine 1725. s Jakovom Kačićem iz rimskih je katakombi donio posmrtne ostatke nepoznatog mučenika kojem je ondašnji biskup Nikola Bijanković nadjenuo ime sv. Klementa. Svetac čije su relikvije smještene u prvom bočnom istočnom oltaru makarske katedrale, postao je zaštitnikom grada Makarske i nekadašnje Makarske biskupije. NIKOLA ALAČEVIĆ, Slavni i zaslužni muževi. Makarska i Primorje. Izlet na Biokovo, pretisak iz 1910. godine, Matica hrvatska Makarska, Makarska, 1998., 66; PETAR KAER, Makarska i Primorje, Tiskarski umjetnički zavod »Miriam«, Rijeka, 1914., 19, bilj. 1-3, 21. Antun Ivanišević svojim je djelovanjem bio vezan uz makarsku katedralu pa je tako 1756. dao u njoj napraviti grobnicu za sebe i svoju obitelj. Nadgrobna ploča s latinskim natpisom (ANTONIUS IVANISCEVICH / SIBI ET / HAEREDIBUS / AN: DO: MDCCLVI) i obiteljskim amblemom poslije je prenesena na gradsko groblje Svetog Križa, osnovano u 19. stoljeću. 
Vidi: PETAR KAER (bilj. 2), 22-23; TATIJANA GARELJIĆ (bilj. 1), 41. Posjedovali su i grobnicu u franjevačkoj crkvi u Makarskoj s natpisom: SEPOLTVRA / DANTONIO / IVANISEVICH / E SVOI EREDI. PETAR KAER (bilj. 2), 36.

3 TATIJANA GARELJIĆ (bilj. 1), 42-43.

4 ANTE JOSIP SOLDO, Prilozi proučavanju agrarno-društvenih odnosa u Gornjem primorju od XVI do polovine XIX stoljeća, u: Makarski zbornik: zbornik znanstvenog savjetovanja o Makarskoj i Makarskom primorju 28-30. rujna 1969., (ur.) Jakša Ravlić, JAZU, Makarska, 1970., 337-380.

5 Ibid., 362-363. Soldo iznosi arhivske podatke (bilježnički spisi) o seljacima s Makarskog primorja koji su se zaduživali kod lokalnog plemstva, a u slučaju neisplate duga, plemići bi se naplatili uzimanjem zemljišnih posjeda. Tako su primjerice Zaostrožani 1782.-1783. godine, za vrijeme velike gladi u Dalmaciji, uzeli žita na dug kod već spomenutog trgovca Jakova Ivaniševića iz Makarske.

6 Od utvrđenoga ladanjskog sklopa u Gradcu sačuvao se tek obrambeni zid s puškarnicama koji je opasavao sklop, međutim, Anita Gamulin ne navodi da je pripadao Ivaniševićima: ANITA GAMULIN, Utvrde Gornjeg makarskog primorja, Makarsko primorje, 4 (1999.), 35-63. Sklop u Tučepima, smješten na morskom žalu, također je gotovo u potpunosti devastiran. S južne, morske strane sačuvao se visoki obrambeni zid s ophodom (balkon-šetnicom) na plitkim svodovima i konzolama, kao i rustični portal kojim se pristupalo u dvorište popločano oblucima. Stambena katnica U-tlocrta jest pregrađena. Obiteljski ljetnikovac u Igranama, $s$ privatnom kapelicom posvećenom Gospi od Ružarija, također smješten uz more, jedan je od najljepših primjera ladanja na Makarskom primorju. Vidi: ZORAIDA DEMORI STANIČIĆ, Ladanjska arhitektura na Makarskom primorju, u: Kultura ladanja: zbornik radova sa znanstvenih skupova "Dani Cvite Fiskovića» održanih 2001. i 2002. godine, (ur.) Nada Grujić, Institut za povijest umjetnosti, Odsjek za povijest umjetnosti Filozofskog fakulteta u Zagrebu, Zagreb, 2006., 131-142, gdje se, između ostalog, navodi da je uništeni sklop u Gradcu pripadao Ivaniševićima. Gospodarsku kuću Ivaniševića u Gradcu, vezanu uz ribolov, ponajviše srdela, spominje i: PETAR KAER (bilj. 2), 108.

7 Ljetnikovac (čest. 288) je ucrtan u austrijskom katastru na mapi broj XII, kao i ruševna gospodarska zgrada (čest. 287) na pašnjaku (čest. 5544) uz ljetnikovac. Kao vlasnik ladanjsko-gospodarskog sklopa (Casa d'abitazione ad un piano con stalla, cucina, corte ad orto con frutta), ruševine i zemljišnih posjeda uokolo ljetnikovca navodi se Josip Ivanišević, sin pokojnog Jakova iz Makarske. Državni arhiv u Splitu (dalje: DAST), HR-DAST-152, Arhiv mapa za Dalmaciju, k. o. Podgora, Upisnik čestica zgrada iz 1835. godine, k. 455/1, str. 29-30; Upisnik čestica zemlje iz 1835. godine, k. 455/1, str. 555-556. Stranice su naknadno numerirane. Obitelj je imala i posjede na Vrutku u Podgori, pa je tako Klement Ivanišević 1795. godine angažirao majstore nastanjene u Makarskoj, Salvadora Visaggia i Marka Fintanu, pok. Jakova, da mu sagrade zid na tom području. NEVENKA BEZIĆ-BOŽANIĆ, Iz prošlosti Podgore u XVIII stoljeću, Čakavska rič, 10 (1982.), 33-50. Spomenuti Klement Ivanišević bio je član makarskog zbora što se okupljao i vijećao pod stoljetnim brijestovima ispod franjevačkog samostana, te sudac u Makarskoj. JAKŠA RAVLIĆ, Makarska i njezino Primorje, dopunjeno i izmijenjeno izdanje, Matica hrvatska Makarska, Makarska, 2000., 89-90. O tome da su Makarani u 18. stoljeću posjedovali zemljišta u Podgori koja je obrađivalo lokalno stanovništvo kao njihovi koloni vidi: NEVENKA BEZIĆ-BOŽANIĆ (bilj. 7), 46, 49, bilj. 17.

8 MIROSLAV KECSKEMETY, Makarska, Hrvatska štamparija S. Vidović, Split, 1934., 13.

9 CVITO FISKOVIĆ, Spomenici grada Makarske, u: Makarski zbornik: zbornik znanstvenog savjetovanja o Makarskoj i Makarskom primorju 28-30. rujna 1969., (ur.) Jakša Ravlić, JAZU, Makarska, 1970., 213-277.

10 KRUNO PRIJATELJ, Barok u Dalmaciji, u: ANĐELA HORVAT, RADMILA MATEJČIĆ, KRUNO PRIJATELJ, Barok u Hrvatskoj, Sveučilišna naklada Liber, Odjel za povijest umjetnosti Centra za povijesne znanosti, Društvo povjesničara umjetnosti Hrvatske, Zagreb, 1982., 649916.
11 KONSTANTA MUCIĆ, Kulturna i prirodna baština Makarskog primorja: Makarska, Makarsko primorje, 7 (2005.), 221-277.

12 ZORAIDA DEMORI-STANIČIĆ (bilj. 6), 133.

13 Palače su prikazane na prvom Corirovu katastarskom planu koji je objelodanio: STANKO PIPLOVIĆ, Posjedi Franjevačkog samostana u Makarskoj u 18. stoljeću, Makarsko primorje, 4 (1999.), 65-75. Iako autor kaže da su na jugozapadnoj granici posjeda franjevačkog samostana ucrtane »kuće Ivanišević", ne dovodi ih izravno u vezu s onima koje su tema ovog rada. Usp. STANKO PIPLOVIĆ (bilj. 13), 68.

14 Ibid., 65-66.

15 Don Pavlovo ime poslije je prekriženo i upisano je Franjino. DAST, HR-DAST-152, Arhiv mapa za Dalmaciju, k. o. Makarska, mapa br. X; k. 334, Upisnik čestica zgrada iz 1835., str. 3-4. Stranice su naknadno numerirane. Franjo je bio istaknuta ličnost devetnaestostoljetne Makarske. Obnašao je dužnost makarskog gradonačelnika, bio je sindikom franjevačkog samostana u Makarskoj, članom općinskog vijeća, kao i članom uprave mjesnog Società di Casino. TATJANA RADAUŠ, KARLO JURIŠIĆ (bilj. 2), 141. Franjin stric don Pavao 1782. godine pristupio je Kongregaciji sv. Filipa Nerija, a nakon što je red ukinut, postao je nakratko profesor u makarskoj gimnaziji. TATJANA RADAUŠ, KARLO JURIŠIĆ (bilj. 2), 140-141. Kaer piše da je imao bogatu knjižnicu u obiteljskoj kući. PETAR KAER (bilj. 2), 88. Godine 1786. u Veneciji je pregovarao s mletačkim kiparom Petrom Onighom oko gradnje glavnoga katedralnog oltara u Makarskoj čiju je izradu financirala Bratovština Presvetog Otajstva. CVITO FISKOVIĆ (bilj. 9) 231-234, bilj. 72; NEVENKA BEZIĆBOŽANIĆ (bilj. 2), 113.

16 Istočno je krilo srušeno tijekom bombardiranja Makarske u Drugom svjetskom ratu, te je nanovo podignuto.

17 Kapelicu spominje: PETAR PUHARIĆ, Zavičajne uspomene, knj. 2, Matica hrvatska, Ogranak, Makarska, 2005., 157.

18 Komparativne primjere takvog tipa stubišta kod dubrovačkih baroknih palača vidi: KATARINA HORVAT-LEVAJ, Barokne palače u Dubrovniku, Institut za povijest umjetnosti, Zagreb, 2001., 74-82.

19 CVITO FISKOVIĆ (bilj. 9), 266.

20 ZORAIDA DEMORI-STANIČIĆ (bilj. 6), 133.

21 Plan Makarske iz 1804. godine vidi u: CVITO FISKOVIĆ (bilj. 9), 216, a onaj iz 1805. vidi u: ARSEN DUPLANČIĆ, Makarska na crtežima i planovima do sredine XIX. stoljeća, Makarsko primorje, 1 (1990.), 115-128.

22 Palača (čest. 27) se 1835. godine navodi u dvojnom vlasništvu sinova posjednika Klementa Ivaniševića iz Makarske, a ruševine (čest. 25 i 26) na mjestu nekadašnjega zapadnog krila kao vlasništvo Josipa i Franje Ivaniševića. Na Franju je upisano i ograđeno dvorište palače (čest. 24), kao i naknadno izgrađena Stalla u njegovu jugoistočnom uglu koja i danas postoji u nešto izmijenjenom obliku. DAST, HR-DAST-152, Arhiv mapa za Dalmaciju, k. o. Makarska, mapa br. X; k. 334, Upisnik čestica zgrada iz 1835., str. 4. Stranice su naknadno numerirane. Usporedimo li podatke iz austrijskog katastra o vlasnicima objekata s onima koje donosi Vjekoslav Cezar Pavišić, vidimo da se pod rednim brojem 128 i 129 nalazi »južna« palača Ivanišević, odnosno njezino zapadno i sjeverno krilo, a pod brojem 127 jest »sjeverna« palača: VJEKOSLAV CEZAR PAVIŠIĆ, Smrt i zavičaj: pobožna uspomena, Tipografia sociale Spalatina, Split, 1895., 25.

23 Jedna se kasnobarokna kruna bunara, kružnog dna i četvrtastog otvora, nalazi u dvorištu kuće (Obala kralja Tomislava 26) na poluotoku Sveti Petar u Makarskoj. S prednje strane ima raskošno oblikovan grb, dok su joj ugaoni istaci otvora ukrašeni cvjetovima. Do pisanja ovog rada nije se uspjelo saznati odakle je i kada dislocirana te je li izvorno pripadala nekoj makarskoj palači.

24 Visina je $78,5 \mathrm{~cm}$, promjer otvora $71 \mathrm{~cm}$, a promjer dna $60 \mathrm{~cm}$.

25 Ovaj zid što se protezao $s$ istočne strane dvaju sklopova te ih je dijelio od maslinika i zatvarao im dvorišta, ucrtan je kod P. Corira 1767., a zatim ponovno u austrijskom katastru iz 1835. godine. Sačuvao se u svom sjevernom dijelu. S unutrašnje (dvorišne) strane zida jesu niše za odlaganje predmeta te jedna koja svojim oblikom nalikuje na zidnu kapelicu sa zidanim oltarićem. Za podatak o kruni bunara i izvoru bočate vode zahvaljujem kolegi M. Tomasoviću. 
26 CVITO FISKOVIĆ (bilj. 9), 239. Dimenzije iznose: visina $95 \mathrm{~cm}$, promjer otvora $98 \mathrm{~cm}$, promjer dna $64 \mathrm{~cm}$.

27 Ibid., 272, bilj. 152. Pored dislocirane krune bunara obitelji Ivanišević leži i jedna stara kamenica.

28 OTOKAR LAHMAN, Prilog proučavanju strukture stanovništva Makarske, Zbornik za narodni život i običaje Južnih Slavena, 42 (1964.), 559-584.

29 NEVENKA BEZIĆ-BOŽANIĆ (bilj. 7), 39, 42, 48, bilj. 10.

30 NEVENKA BEZIĆ-BOŽANIĆ (bilj. 2), 105, gdje se navodi da je majstor T. Miraglia u knjigu bratovštine upisan 1757. godine.

31 DARKA BILIĆ, Izgradnja zvonika katedrale u Makarskoj, Prilozi povijesti umjetnosti u Dalmaciji, 42 (2011.), 307-322, navodi da "je izradio dio svoda lođe zvonika«.

\section{REFERENCES}

NIKOLA ALAČEVIĆ, Slavni i zaslužni muževi. Makarska i Primorje. Izlet na Biokovo, reprint, Matica hrvatska Makarska, Makarska, 1998.

NEVENKA BEZIĆ-BOŽANIĆ, Iz prošlosti Podgore u XVIII stoljeću, Čakavska rič, 10 (1982), 33-50.

NEVENKA BEZIĆ-BOŽANIĆ, Prilog poznavanju bratovština u Makarskoj u 18. stoljeću, Makarsko primorje, 1 (1990), 103-114.

DARKA BILIĆ, Izgradnja zvonika katedrale u Makarskoj, Prilozi povijesti umjetnosti u Dalmaciji, 42 (2011), 307-322.

ZORAIDA DEMORI STANIČIĆ, Ladanjska arhitektura na Makarskom primorju, in: Kultura ladanja: zbornik radova sa znanstvenih skupova "Dani Cvite Fiskovića" održanih 2001. i 2002. godine, (ed.) Nada Grujić, Institut za povijest umjetnosti, Odsjek za povijest umjetnosti Filozofskog fakulteta u Zagrebu, Zagreb, 2006, 131-142.

ARSEN DUPLANČIĆ, Makarska na crtežima i planovima do sredine XIX. stoljeća, Makarsko primorje, 1 (1990), 115-128.

CVITO FISKOVIĆ, Spomenici grada Makarske, in: Makarski zbornik: zbornik znanstvenog savjetovanja o Makarskoj i Makarskom primorju 28-30. rujna 1969., (ed.) Jakša Ravlić, JAZU, Makarska, 1970, 213-277.

ANITA GAMULIN, Utvrde Gornjeg makarskog primorja, Makarsko primorje, 4 (1999), 35-63.

TATIJANA GARELJIĆ, Grbovi i rodoslovi Makarske i Makarskog primorja, Gradski muzej Makarska, Makarska, 1996.

KATARINA HORVAT-LEVAJ, Barokne palače u Dubrovniku, Institut za povijest umjetnosti, Zagreb, 2001.
PETAR KAER, Makarska i Primorje, Tiskarski umjetnički zavod "Miriam”, Rijeka, 1914.

MIROSLAV KECSKEMETY, Makarska, Hrvatska štamparija S. Vidović, Split, 1934.

OTOKAR LAHMAN, Prilog proučavanju strukture stanovništva Makarske, Zbornik za narodni život i običaje Južnih Slavena, 42 (1964), 559-584.

KONSTANTA MUCIĆ, Kulturna i prirodna baština Makarskog primorja: Makarska, Makarsko primorje, 7 (2005), 221-277.

VJEKOSLAV CEZAR PAVIŠIĆ, Smrt i zavičaj: pobožna uspomena, Tipografia sociale Spalatina, Split, 1895.

STANKO PIPLOVIĆ, Posjedi Franjevačkog samostana u Makarskoj u 18. stoljeću, Makarsko primorje, 4 (1999), 65-75.

KRUNO PRIJATELJ, Barok $u$ Dalmaciji, in: ANĐELA HORVAT, RADMILA MATEJČIĆ, KRUNO PRIJATELJ, Barok u Hrvatskoj, Sveučilišna naklada Liber, Odjel za povijest umjetnosti Centra za povijesne znanosti, Društvo povjesničara umjetnosti Hrvatske, Zagreb, 1982, 649-916.

PETAR PUHARIĆ, Zavičajne uspomene, Vol. 2, Matica hrvatska, Ogranak, Makarska, 2005.

TATJANA RADAUŠ, KARLO JURIŠIĆ, "Ivanišević (Degl' Ivanissevich, Iuaniseuich, Ivanischevich, Ivanisevich, Ivanisseuich)", Hrvatski biografski leksikon, Vol. 6: I-Kal, (ed.) Trpimir Macan, Leksikografski zavod "Miroslav Krleža", Zagreb, 2005, 140-142.

JAKŠA RAVLIĆ, Makarska i njezino Primorje, updated and revised ed., Matica hrvatska Makarska, Makarska, 2000.

ANTE JOSIP SOLDO, Prilozi proučavanju agrarno-društvenih odnosa $u$ Gornjem primorju od XVI do polovine XIX stoljeća, in: Makarski zbornik: zbornik znanstvenog savjetovanja o Makarskoj i Makarskom primorju 28-30. rujna 1969., (ed.) Jakša Ravlić, JAZU, Makarska, 1970, 337-380.

\section{ARCHIVAL SOURCES}

Državni arhiv u Splitu (DAST), HR-DAST-152, Arhiv mapa za Dalmaciju, k. o. Podgora, Upisnik čestica zgrada iz 1835. godine, k. 455/1, str. 29-30; Upisnik čestica zemlje iz 1835. godine, k. 455/1, str. 555-556.

Državni arhiv u Splitu (DAST), HR-DAST-152, Arhiv mapa za Dalmaciju, k. o. Makarska, mapa br. X; k. 334, Upisnik čestica zgrada iz 1835., str. 3-4. 
Summary

Antonia Vodanović

Two Baroque Country Estates of the Ivanišević Family in Makarska

The paper discusses the architectural legacy of the noble family Ivanišević in Makarska, more precisely their family palaces whose position on the eastern outskirts of the city, surrounded by olive groves to the east and by the sea to the south, characterizes them as country residences, although not entirely separated from urban context. The family also owned residential country estates along the Makarska littoral, erected by the sea in Tučepi, Podgora, Igrane and Gradac.

Of the two palaces in Makarska, only the "south" one was preserved, while the "north" was completely devastated in the course of the $19^{\text {th }}$ and the $20^{\text {th }}$ centuries. It was replaced by a new residential multi-storey building which retained a Baroque portal on its western façade. A $17^{\text {th }} / 18^{\text {th }}$-century wellhead belonging to the earlier structure was preserved in the back garden, as well as a section of a high wall which used to enclose the former two-wing complex. The south palace, characterized by gallery arcades on the north wing, used to hold a rich library and a chapel in the interior. Today it is considered one of the most prominent examples of profane architecture of the Baroque period in the Makarska littoral. 